\title{
A Review of Environmental Management Systems in Global Defence Sectors
}

\author{
${ }^{1}$ Xiao Hua Wang and ${ }^{1,2}$ Wen Wu \\ ${ }^{1}$ School of Physical, Environmental and Mathematical Sciences, \\ University of New South Wales Canberra, Canberra ACT 2600, Australia \\ ${ }^{2}$ College of Physical and Environmental Oceanography, Ocean University of China, Qingdao 266100, China
}

Received 2012-06-04, Revised 2012-12-14; Accepted 2013-05-14

\begin{abstract}
Environmental management is a key element in ensuring positive environmental performance of an organization. The integration of environmental management into military activities has also become a growing concern for defence sectors internationally. At present, an Environmental Management System (EMS) is one of the most widely used environmental management tools throughout the world. Recent research and public concerns have been increasingly concentrated on EMS implementation and evaluation, examining how an EMS improves environmental performance. This study provides a literature review mainly on several areas: EMS related concepts, its application and evaluation methods in global defence sectors. It is found that there are no significant differences in the EMS adoption and implementation between different countries and defence sectors. Currently, there is no universal method for EMS evaluation. A case-by-case approach is preferred as long as evidence can be found to provide support for the evaluation of an EMS. Based on the review, relevant recommendations are discussed from aspects, such as environmental performance indicator, independent evaluation, data and information collection and environmental monitoring and reporting, that should help to ensure the EMS a helpful tool for sustainable environmental management. This review provides a general overview, identifies knowledge gaps and highlights aspects of the research regarding EMS implementation and evaluation; it is useful for strengthening the EMS operation, clarifying the relationship between the use of an EMS and environmental performance and producing operational guidelines for evaluating an EMS.
\end{abstract}

Keywords: Environmental Management System (EMS) Application, Defence Sector, Evaluation Methods, Environmental Performance, Public Concerns, Performance Indicator

\section{INTRODUCTION}

Environmental management has gained in importance around the world in recent years, with many strategies emerging as the times require (Kolk and Mauser, 2002; Ann et al., 2006; Anderson et al., 2007; Rashed et al., 2008). The growing demand for effective and integrated environmental management has resulted from various factors, such as increasingly complex and uncertain environmental situations, introduction of environmental legislation, growing environmental concerns and demands for better resource management and reduced environmental pollution (Chin et al., 1999; Bowers and Cornish, 2000; Strachan et al., 2003; Rao, 2005; Reed, 2008).

Environmental management is a complex mechanism involving many important issues, such as operations and technologies, products and services, functional strategies and management systems (Klassen and Mclaughlin, 1996; Kolk and Mauser, 2002).

Corresponding Author: Wen Wu, College of Physical and Environmental Oceanography, Ocean University of China, Qingdao 266100, China 
Environmental management is considered as a methodology for managing the operations of an organisation to ensure they are performed in an environmentally responsible manner. It can also be seen as the sensible utilisation and management of environmental resources in a cost-effective and sustainable way (Hale, 1995).

At present, there are many environmental management tools in use, such as environmental impact assessments, environmental auditing, substance flow analysis, life-cycle assessments and environmental management systems (Emilsson and Hjelm, 2002; Ramos et al., 2009). These tools provide environmental information and assist environmental management in order to make organisations more environmentally friendly (Emilsson and Hjelm, 2002). Of these tools, an Environmental Management System (EMS) is one of the most commonly used in organisations worldwide (Zutshi et al., 2008; Nawrocka and Parker, 2009; Ramos et al., 2009). To date, the International Organization for Standardization (ISO) 14001 is the only international standard for the development and implementation of an EMS (Sinclair and Tschirhart, 2001; NHDES, 2002).

Recent research has focused on evaluating an EMS's effectiveness and environmental performance relative to the ISO14001 standard, rather than investigating its adoption and development in an organisation (NHDES, 2002; Dawson, 2004; Hertin et al., 2008; Nawrocka and Parker, 2009). Although there have been many studies on the connection between an EMS and environmental performance, quantitative evidence is lacking (Hertin et al., 2008). This study reviews the EMS implementation and evaluation in global defence sectors.

The environmental management of military activities is a growing concern for defence forces worldwide (Ramos and Melo, 2005; 2006; Bioce, 2006; Anderson et al., 2007; Ramos et al., 2007a). As an essential part of society, the defence sector is a large, complex and important social organisation (DD, 2003) and its military activities are closely interrelated with the environment. Defence authorities all over the world recognise that sustainable environmental management is a key issue in keeping military activities effective in the long run (Ramos and Melo, 2005). As Diecidue (2008) stated, "increased environmental diligence and scrutiny can result in increased military readiness".

Defence's management of the natural environment, especially sensitive ecosystems, has been a hot and complicated research topic (Ramos and Melo, 2005); some baseline studies related to this issue have already been conducted. Military training activities have impacts on the environment (Kreizenbeck, 2004). Many military training areas are located in environmentally sensitive regions (e.g., protected areas and water catchments) (Rao, 2005; Godschalk, 2007). As Leitmann (1998) noted, from a survey of protected areas conducted by the International Union for Conservation of Nature, military activities are one of their top ten threats. There is also increasing public concern about military training activities and their environmental impact (DD, 2003, 2009). Given that environmental challenges and demands on management are increasing, the integration of environmental management into defence sectors should be a focus in military operations. It is also important to examine how effective an EMS is as a tool for environmental management of military training activities.

\subsection{The Environmental Management System (EMS) and its Application in Global Defence Sectors}

\subsubsection{The EMS and its Standards}

The EMS is a management tool to help organisations identify potential environmental impacts, protect the environment and manage their daily activities in an environmentally friendly way. Environmental management actions and protection obligations can be delivered with the help of an EMS (Andrews et al., 1999; Darnall et al., 2000; Beeby, 2008; DSEWPaC, 2008). Various definitions of an EMS have been documented in the literature, for example: NHDES (2002); ISO (2004); Rao (2005); Arimura et al. (2008); Zutshi et al. (2008). Generally speaking, an EMS is a comprehensive and well-organised management system with systematic processes and procedures that allow an organisation to plan its environmental activities, assess and manage its environmental aspects and impacts, produce and implement its environmental policies and achieve its environmental objectives.

Since the 1990s, several standards applying to an EMS have been established, such as the British Standard 7750 (BS7750), the Eco-Management and Auditing Scheme (EMAS) and the ISO14001 (NHDES, 2002; Moore, 2004).

The BS7750 was the first standard for an EMS produced by the British Standards Institute in March 1992 (DD, 2002; North Atlantic Treaty Organization Committee on the Challenges of Modern Society (NATO-CCMS), 2000). The standard provides a 
framework to implement an EMS, which includes environmental policy, targets and objectives, environmental risk management and auditing. Its limitations include a lack of detailed criteria for evaluation of environmental performance. Although replaced by the ISO14001 in March 1997, the BS7750 provided a foundation for the development of other significant EMS standards (DD, 2000; Rowland-Jones et al., 2005).

The EMAS was initially published in Official Journal L168 in July 1993 and launched in the United Kingdom (UK) in April 1995. The EMAS has been widely used in European Union organisations (NATOCCMS, 2000; Rowland-Jones et al., 2005). Designed under the European Union (EU)'s Fifth Environmental Action Program, it was used in the private sector in the first instance. It then spread to a large range of EU organisations excluding the UK, mainly focusing on industrial actions. Although the EMAS was set up as a voluntary mechanism, all EU member states are now required to comply with it. Further elements were subsequently added to the EMAS, such as environmental policy, the EMS implementation, environmental commitment, monitoring and auditing, public communication, review and continual improvements (DD, 2000; NATO-CCMS, 2000). Third-party auditing is also required in the EMAS (Cheesbrough, 2006).

The ISO is a Non-Government Organisation (NGO) established in 1947 and now comprises approximately 100 national standard entities (Edwards et al., 1999; Arimura et al., 2008). It is the largest institution in the world involved in developing voluntary international standards (ISO, 2007). In 1991, this organisation formed a Strategic Advisory Group on the Environment (SAGE) to examine the demand for the establishment of an international environmental management standard (Strachan et al., 2003; Rowland-Jones et al., 2005). Following SAGE requirements, an official Technical Committee (TC-207) was formed and, with its help, a large number of standards concerning environmental management issues have been produced (Strachan et al., 2003; Potoski and Prakash, 2005; Rowland-Jones et al., 2005). One of their most significant outcomes was an International Standard for an EMS, the ISO14001, first called for at the 1992 Rio Summit and subsequently completed in Geneva, Switzerland in September 1996 (Rondinelli and Vastag, 2000; Rao, 2005).

The ISO14001 is the first EMS standard used internationally. It is regarded as the international benchmark for organisations in implementing and evaluating environmental management practices and has been accepted and implemented widely (Edwards et al., 1999; Gallagher et al., 1999; Maier and Vanstone, 2005).
A voluntary EMS standard, the ISO14001, provides a systematic and integrated management framework for an organisation to operate their environmental management activities and bring good environmental practice to the entire organisation (Morrow and Rondinelli, 2002; Welch et al., 2002; Melnyk et al., 2003; Ann et al., 2006). The content of the ISO14001 EMS includes:

- Fulfilling environmental legislation requirements

- Setting environmental policy

- Clarifying objectives and targets for environmental performance

- Identifying environmental aspects and impacts

- Mitigating environmental pollution and harmful impacts

- Training and monitoring, checking and auditing EMS implementation

- Communicating with the public

- Evaluating environmental performance

- Documenting environmental management procedures

- Reviewing and continually improving management practices

The ISO14001 uses Plan-Do-Check-Act (PDCA) to establish the EMS process (Arimura et al., 2008; Rashed et al., 2008). Details are given in Table 1. The ISO14001 document gives detailed guidelines on how to establish, implement, evaluate and improve an EMS at every stage (ISO, 2004). There are several outstanding advantages of this standard. For example, it emphasises the significance of identifying environmental impacts and taking precautionary controlling measures at the earliest possible stage. Continual improvement of the EMS and environmental performance is a focal point at all times (Andrews et al., 1999; Lundberg et al., 2005).

Some countries, such as Canada, France, Ireland, Spain and South Africa, have produced their national standards (NATO-CCMS, 2000). All these standards aim to achieve effective environmental management. In view of differences between these national standards, the ISO14001 is regarded as the worldwide EMS standard for organisations to adopt, because it is the only standard widely accepted by a large number of countries (Sinclair and Tschirhart, 2001; NHDES, 2002).

The adoption and implementation of the ISO14001 EMS therefore have many advantages and benefits for an organisation (Dahlstrom et al., 2003; Dawson, 2004; Rashed et al., 2008; Zutshi et al., 2008). 
Table 1. Plan-Do-Check-Act methodology with the ISO14001 EMS requirements (ISO, 2004; Anderson et al., 2007; Arimura et al., 2008)

\begin{tabular}{|c|c|c|}
\hline PDCA & Requirements of the ISO14001 & EMS stages \\
\hline \multirow[t]{2}{*}{ Plan } & $\begin{array}{l}\text { Define an environmental policy that is compatible with the } \\
\text { organisation's specific characteristics } \\
\text { Include commitment to EMS framework, such as compliance with legislation, } \\
\text { environmental protection principles and future improvement }\end{array}$ & \\
\hline & $\begin{array}{l}\text { Make it known to organisation personnel and the public } \\
\text { Develop an Environmental Management Plan, identify environmental aspects, } \\
\text { impacts and legal requirements and formulate objectives, targets } \\
\text { and program of environmental management }\end{array}$ & Commitment and environmental policy \\
\hline \multirow[t]{2}{*}{ Do } & $\begin{array}{l}\text { Comply with the environmental policy } \\
\text { Implement the EMS processes to achieve the commitment to } \\
\text { environmental policy, objectives and targets }\end{array}$ & Planning \\
\hline & $\begin{array}{l}\text { Clarify roles and responsibilities, allocate resources, conduct awareness } \\
\text { and management training, communicate with the public, control environmental }\end{array}$ & \\
\hline Check & $\begin{array}{l}\text { damage, respond and report environmental incidents } \\
\text { Monitor and evaluate the environmental performance to examine whether } \\
\text { the EMS implementation fulfils the environmental policy, achieves objectives } \\
\text { and targets, complies with legal requirements }\end{array}$ & Implementation and operation \\
\hline & Conduct internal audits & Checking and evaluation \\
\hline Act & $\begin{array}{l}\text { Review the entire EMS process, determine its feasibility and effectiveness } \\
\text { Find ways to improve EMS performance and management }\end{array}$ & $\begin{array}{l}\text { Management review and continual } \\
\text { improvement }\end{array}$ \\
\hline
\end{tabular}

Amongst these benefits, it can help to:

- Improve environmental performance and management efficiency

- Ensure compliance with stringent environmental legislation

- $\quad$ Promote environmental policy

- Identify and reduce environmental risks and potential environmental impacts

- Mitigate environmental pollution and protect resources and ecosystems

- Motivate effective EMS implementation

- Enhance internal and external communications and cooperation with stakeholders and the public

- Reduce environmental management costs

- Minimise environmental liability

- Strengthen public awareness and concern for the environment and its management

- Provide a mechanism to certify an organisation's leading role in environmental management; and

- Resolve problems regarding environmental goals in a timely fashion

\subsection{Application of the ISO14001 EMS in Global Context}

There is a global trend to increased usage of an EMS (Hui et al., 2001; Zutshi et al., 2008; Nawrocka and
Parker, 2009). More and more organisations, such as industries, companies, government agencies and other social groups, are introducing and implementing the ISO14001 EMS (Rondinelli and Vastag, 2000; Welch et al., 2002; Schylander and Martinuzzi, 2007). According to the ISO Survey of Certifications 2009, there were more than 223,149 certified ISO14001 EMSs in 159 countries/economies in 2009 (Frost, 2010), approximately $18 \%$ more than in 2008 .

As the EMS was initially designed for industrial sectors, it is used widely in both developed and developing countries in industries, firms and companies, such as chemical, electronics, auto manufacturing, computers, energy and wastewater management (Darnall et al., 2000; NATO-CCMS, 2000; Zutshi and Sohal, 2001; Melnyk et al., 2003; Ramos and Melo, 2005; Arimura et al., 2008; Zutshi et al., 2008). It should be noted that, to be certified, an EMS's implementation must conform to all the ISO14001 requirements (Rao, 2005; Nawrocka and Parker, 2009). The EMS is not a static management tool; it must be developed and improved continuously (DD, 2000).

\subsection{Defence sectors and their Environmental Management Practices}

The United Nations' (UN) Millennium Project, which focuses on the achievement of the Millennium Development Goals by 2015 as agreed by UN members, 
highlights the importance of more-responsible environmental stewardship being exhibited by defence forces worldwide (Diecidue, 2008). Defence organisations are among the most significant institutions in society, with their primary mission to defend their nation's security and sovereignty, as well as people's interests and rights (DD, 2007; Ramos et al., 2007a; 2007b). Preparedness for and achievement of these goals need to be supported by a series of elements, including sophisticated weapons and equipment, qualified military personnel, high-quality training areas with adequate facilities, satisfactory resources and environment and integrated management (Doxford and Hill, 1998; Kreizenbeck, 2004; Ramos and Melo, 2005).

Defence sectors throughout the world own large areas of land (Linkov and Ramadan, 2004; Ramos et al., 2007a). Many training areas are located in environmentally sensitive regions, such as protected areas, agricultural land, water catchments and significant heritage areas (Rao, 2005; Godschalk, 2007). Conflict was the central point regarding establishment and environmental maintenance of protected areas. There have been many prominent disputes arising between military use and environmental reserves (West et al., 2006), such as at the Otterburn Military Training Area and Northumberland National Park in the UK (Doxford and Savege, 1995; Doxford and Hill, 1998). In this case, rigorous area-use planning and public inquiries were required eventually to allow both uses and achieve harmonious development (Doxford and Savege, 1995).

Another example was the Dartmoor Training Area, used for military training for more than 200 years and located within a significant national park in the UK. The Ministry of Defence and the Association of National Park Authorities found that the best way to resolve the conflict was cooperation and a Declaration of Intent was signed in 2005 to ensure a close relationship. The ISO14001 EMS was adopted for use in that area in 2002 (DNPA, 2005). In 2005, an external audit of the Dartmoor Training Area EMS was conducted to ensure all impacts were identified and to recommend the future development of the EMS (RPSHSE, 2005). A similar cooperative initiative between the defence force and local communities regarding the Makalu-Barun Conservation Area in Nepal was highlighted in the study of Mehta and Kellert (1998).

An example of Australia is related to Shoalwater Bay Training Area (SWBTA), Queensland. In 1993-94, a Commission of Inquiry into the Shoalwater Bay area was established to assess the compatibility of the multiple uses made of and activities undertaken, at SWBTA from an environmental perspective. A series of recommendations were made, one of which was that military use and conservation should have equal significance and that environmental protection and management should be promoted in future military activities at SWBTA (Woodward, 1994; DD, 2009).

In peacetime, defence forces spend most of their time on military training and operations with peaceful purposes (Godschalk, 2007). Good environmental practice should be integrated into all defence force activities, that is, "the environment should be treated as an element of military doctrine and ingrained in security considerations and not separate from them" (Diecidue, 2008).

\subsection{Empirical Studies on Environmental Impacts of Military Activities}

Major environmental impacts of military training (e.g., traffic, bombing, live firing and vehicle manoeuvres) include: soil erosion and compaction; landscape change; water and waste pollution; noise and air pollution; disturbance of flora and fauna; ecosystem and environmental destruction; and impacts on human health and safety (Cuddy et al., 1990; Ramos and Melo, 2005; Rao, 2005; Ramos et al., 2007a). The impact might vary considerably from area to area, depending on the military activities conducted and the environmental features of training areas (Linkov and Ramadan, 2004).

There have been a number of studies concerning military disturbances and environmental effects on land (Wilson, 1988; Ayers, 1994; Lehman et al., 1999; Hirst et al., 2000; Whitecotton et al., 2000; Smith et al., 2002; Williams et al., 2005; Leis et al., 2005; 2008; Latham et al., 2007; Warren et al., 2007). These studies have used field experiments, observations, data monitoring and technical methods such as a Geographic Information System (GIS), computer simulation and multi-criteria analysis (Warren et al., 1989; Mendoza et al., 2002; Herl et al., 2005; Wang et al., 2008). The majority of these study areas are located in the United States of America (USA) and the UK, with both countries relatively advanced in this type of research. Understanding the environmental impacts of military activities is considered necessary so that the defence authorities can take measures to mitigate or prevent these negative impacts (Diecidue, 2008). These studies and applied technologies have helped to establish many management strategies, such as Integrated Training Area Management in the USA and the 
Combined Arms Tactical Trainer and Integrated Land Management Plan in the UK (Doxford and Hill, 1998; Durant, 2007).

\subsection{Application of the ISO14001 EMS by Defence sectors in Different Countries}

An increasing number of countries are integrating environmental management into military activities using the ISO14001 EMS (Dawson, 2004; Ramos and Melo, 2005; 2006; RPSHSE, 2005). NATO set an early example, with environmental management operations in place since the 1990s (Kreizenbeck, 2004). The Committee on the Challenges of Modern Society (CCMS) of NATO led the way in EMS adoption in defence sectors by conducting a NATO-CCMS Pilot Study on Environmental Management Systems in the Military Sector in 2000. It emphasised the advantages of an EMS and recommended the implementation of this tool in military activities. The study report also summarised the ISO14001 EMS guidelines and implementation, using diverse examples gathered from defence sectors in EU countries (NATO-CCMS, 2000). The report found that environmental management of most military activities was better integrated when the ISO14001 EMS was in operation. After the release of the pilot study, several workshops were held to find ways of filling the gaps between EMS theory and practice (Sinclair and Tschirhart, 2001; Dawson, 2004). The NATO Standardization Agreement for Environmental Protection was also promulgated to support the NATO-led environmental management of military activities (Ramos and Melo, 2005; 2006; Ramos et al., 2007a).

Australia has also become increasingly concerned with its environmental management practices and the ISO14001 standard has been adopted by various organisations (DD, 2003; Bioce, 2006; Beeby, 2008). Many institutions, such as the Commonwealth and State Governments and Standards Australia, are promoting the implementation of the ISO14001 EMS (Zutshi and Sohal, 2001). The Australian Government required all Commonwealth agencies and departments to have a certified EMS in place by the end of 2003 (DD, 2003; 2005). As a follow-up action, the AS/NZS (Australian/New Zealand Standard) ISO14001 (2004) was instituted specifically for Australian environmental management (SASNZ, 2000).

As one of the largest Australian Government landowners, the Australian Defence Force (ADF) also recognises its environmental management responsibilities (Cuddy et al., 1990; Scott et al., 2000; DD, 2003). To comply effectively with environmental legislation and implement defence environmental strategies, in 2001 the ADF adopted an integrated EMS under the ISO14001 standard as the guiding framework for incorporating environmental performance into dayto-day military business (Beeby, 2008). Its central point is to provide an integrated and directive tool for successful environmental management by the ADF. The ADF EMS model is shown in Fig. 1. A set of executive guidelines and measures have been developed by the $\mathrm{ADF}$ in accordance with its EMS to facilitate environmental management. Extensive environmental management activities with regard to the ADF EMS modules have been discussed by Wu et al. (2010).

Several examples of the adoption and development of an EMS by defence forces of different countries are reviewed in Table 2. For these cases, an EMS is recognised as a critical tool in achieving the best possible performance and being a leader in environmental management (Kusnir, 2004; Moore, 2004). Generally speaking, around the world, defence environmental management is similar in defence missions, legal requirements, environmental management targets, frameworks, policies, plans, implementation tools, existing weaknesses and future improvements. These similarities show that benefits could be gained by information sharing between stakeholders (Linkov and Ramadan, 2004; Kreizenbeck, 2004).

\subsection{Evaluation of EMS Effectiveness}

\subsubsection{EMS and Environmental Performance}

Empirical studies have shown various beneficial outcomes because of an EMS, such as better legal compliance and ecological improvement (Steger, 2000; Potoski and Prakash, 2005). Recently, research and public concerns have become increasingly concentrated on how an EMS is implemented, whether and how it satisfies the ISO14001, the ISO14001 and how it improves environmental performance (Arimura et al., 2008; Hertin et al., 2008; Nawrocka and Parker, 2009). As one of the projects' final report stated, "[it] is not simply whether an EMS is in place or has been certified, but what impacts were identified as significant, what objectives and targets were set for their improvement and what actual performance or compliance results have been achieved" (UNCCHDPP, 2003).

The leading guidance documents regarding EMS and environmental performance have been produced by 
the Organisation for Economic Co-operation and Development (OECD), including Improving the environmental performance of government and Improving the environmental performance of public procurement (Ramos et al., 2007a). In Indonesia, the Ministry of Environment developed a public rating system called "Proper Prokasih" in 1995, in order to strengthen EMS implementation. It has been described as "the first central government program in the world to publish a single index of environmental performance" (Edwards et al., 1999).

An EMS is a widely used policy and management tool. What elements contribute to the successful implementation of an EMS and to what extent can it be considered effective? Although numerous studies have been conducted to evaluate an EMS and environmental performance (NHDES, 2002; UNCCHDPP, 2003; Salmons, 2004; Cheesbrough, 2006; Ramos et al., 2007b; 2009), the answer to this question is still not clear. For example, the study of Melnyk et al. (2003) on American manufacturing industries showed that, as a result of ISO14001 EMS implementations, there was significant improvement in environmental performance in the areas of product quality improvement, waste reduction, efficiency of equipment utilisation and reduction of lead time. The UK Environment Agency believes there is a correlation between an EMS and environmental performance (Maier and Vanstone, 2005). The Ethical Investment Research Services conducted a worldwide survey in 2005 to explore this correlation. It found an evident and positive correlation between the quality of an EMS and the improvement in environmental performance (Maier and Vanstone, 2005).

Nawrocka and Parker (2009) reviewed 23 studies from 1996 to 2008 on the effects of implementing an EMS. They noted that the EMS resulted in improved environmental performance in some studies, but not in others. Several reasons for this were put forward. Firstly, there was not a consistent definition of "environmental performance" in the studies.

\begin{tabular}{|c|c|c|c|c|c|c|}
\hline Country & Defence organisation & ISO14001 EMS & $\begin{array}{l}\text { Environmental } \\
\text { management status }\end{array}$ & Applied legislation & $\begin{array}{l}\text { Principles/guidelines, } \\
\text { strategies, policies, programs }\end{array}$ & $\begin{array}{l}\text { Future improvement } \\
\text { /Comments }\end{array}$ \\
\hline$\overline{\mathrm{UK}}$ & $\begin{array}{l}\text { Ministry of Defence (the } \\
\text { second largest single- } \\
\text { ownership department } \\
\text { following the forestry } \\
\text { commission; holding more } \\
\text { than } 1 \% \text { of the land } \\
\text { area and } 3 \% \text { of the) } \\
\text { national park regions }\end{array}$ & $\begin{array}{l}80 \% \text { of the government estates } \\
\text { with an EMS in place by 2006 } \\
\text { (announced on July 24, 2002); } \\
\text { Carried out by Army, Navy and } \\
\text { Air Force }\end{array}$ & $\begin{array}{l}\text { Formerly relatively } \\
\text { poor record, reformed } \\
\text { in recent years }\end{array}$ & $\mathrm{N} / \mathrm{A}$ & $\begin{array}{l}\text { Specific EMS team; strategic } \\
\text { guidelines e.g. "implementing } \\
\text { environmental management systems } \\
\text { guidance for government departments" } \\
\text { and "sustainable development in } \\
\text { government"); safeguards produced by } \\
\text { defences science and technology laboratory; } \\
\text { significant environmental impacts } \\
\text { identified;management principles regulated }\end{array}$ & $\begin{array}{l}\text { Future improvement: environmental } \\
\text { performance indicator development; } \\
\text { reporting framework; data collection; } \\
\text { public participation }\end{array}$ \\
\hline Netherlands & $\mathrm{N} / \mathrm{A}$ & $N / A$ & $\mathrm{~N} / \mathrm{A}$ & & Defence Environmental Policy Plan & \\
\hline USA & $\begin{array}{l}\text { Department of Defense (the } \\
\text { third largest landholder) }\end{array}$ & $\begin{array}{l}\text { Executive order (EO 13148) } \\
\text { greening the government } \\
\text { through Leadership in } \\
\text { environmenta management } \\
\text { signed calling for the EMS } \\
\text { adoption and implementation } \\
\text { (April 2000); Adopted by all } \\
\text { federa agencies (including } \\
\text { defense) with the EPA requirements } \\
\text { by the end of 2005; Pilot } \\
16 \text { selected military installations } \\
\text { study of } 16 \text { reporting the } \\
\text { extensive use and positive } \\
\text { effect of the ISO14001EMS } \\
\text { in all defence scopes }\end{array}$ & $\begin{array}{l}\text { No concept in military } \\
\text { lands before the 1960s, } \\
\text { and changed along with the } \\
\text { serious environmenta damage } \\
\text { and protection concerns; } \\
\text { Responsibility taken over } \\
\text { from engineering } \\
\text { community (1994) }\end{array}$ & $\begin{array}{l}\text { The clean air act } \\
\text { of } 1970 \text {; federal } \\
\text { water pollution } \\
\text { control act of } 1972 \\
\text { the endangered } \\
\text { species act of } \\
1973 \text { the resource } \\
\text { conservation and } \\
\text { recovery act of } 1976 \text {; } \\
\text { the clean water } \\
\text { act of } 1977\end{array}$ & $\begin{array}{l}\text { integrated natural resource management } \\
\text { Plans (INRMPs) (1989); the army } \\
\text { environmental policy institute (1990); } \\
\text { US army environmental strategy into the } \\
\text { 21st century (1991); guideline for INRMP } \\
\text { preparation (1997); three broad programs } \\
\text { (january 2003): environmental impacts } \\
\text { integration of INRMPs and the ISO14001 } \\
\text { identification EMS; military training } \\
\text { area management (e.g. LCTA (land } \\
\text { condition trend analysis),maintenance), } \\
\text { TRI (training requirements integration), EA } \\
\text { (environmental specific programs (e.g. air } \\
\text { quality and waste management, noise reduction } \\
\text { pollution prevention, fish and wildlife and } \\
\text { endangered species management installation } \\
\text { restoration and reporting system) }\end{array}$ & $\begin{array}{l}\text { The modern status of USA } \\
\text { environmental management } \\
\text { commenced with the implementation } \\
\text { of the national environmental policy } \\
\text { of } 1969 \text { and the establishment of } \\
\text { he US EPA in } 1970 \text {. }\end{array}$ \\
\hline Canada & $\begin{array}{l}\text { Department of National } \\
\text { National Defence and the } \\
\text { Canadian } \\
\text { Forces (DND/CF) }\end{array}$ & $\begin{array}{l}\text { Adopted by Parliament (1995); } \\
\text { complete implementation by april } \\
\text { 2004; adopted by DND/CF" }\end{array}$ & $\mathrm{N} / \mathrm{A}$ & $\begin{array}{l}\text { The Canadian } \\
\text { environmental } \\
\text { assessment } \\
\text { the Canadian } \\
\text { environmental } \\
\text { protectiont }\end{array}$ & $\begin{array}{l}\text { National strategy: the "greening } \\
\text { government" }\end{array}$ & $\begin{array}{l}\text { The first Sustainable Development } \\
\text { Strategy (SDS) (1997) and second } \\
\text { SDS (2000); participant in the } \\
\text { NATO-CCMS pilot study }\end{array}$ \\
\hline Portugal & $\begin{array}{l}\text { Portuguese Ministry of } \\
\text { Defence (MDN) (one of largest } \\
\text { public sectors; holding about } \\
1 / 4 \text { of the territory) }\end{array}$ & $\begin{array}{l}\text { Adopted (2001); now fully } \\
\text { implemented in all defence } \\
\text { branches }\end{array}$ & $\begin{array}{l}\text { Military policy not } \\
\text { ncluded for a long time; } \\
\text { considered more recently }\end{array}$ & $\mathrm{N} / \mathrm{A}$ & $\begin{array}{l}\text { National plan for environmental policy } \\
\text { instituted by the MDN (1995), relevant } \\
\text { strategies, training and management } \\
\text { measures followed. }\end{array}$ & $\begin{array}{l}\text { Participant in the NATO-CCMS } \\
\text { pilot study; future improvement } \\
\text { environmental awareness training; } \\
\text { environmental baseline survey; } \\
\text { environmental impact identification }\end{array}$ \\
\hline South Africa & $\begin{array}{l}\text { South African national } \\
\text { defence Force }\end{array}$ & Developed & $\begin{array}{l}\text { Environmental } \\
\text { responsibilities } \\
\text { acknowledged } 1977\end{array}$ & N/A & $\begin{array}{l}\text { First environmental policy (1978); } \\
\text { sustainable training area management } \\
\text { plan; environmental considerations in } \\
\text { operations; environmental Implementation } \\
\text { plan military integrated environmental } \\
\text { Management methodology }(1990 \mathrm{~s})\end{array}$ & N/A \\
\hline Slovak republi & ic Ministry of Defence & $\begin{array}{l}\text { Developed in the armed forces } \\
\text { (2001) }\end{array}$ & $\begin{array}{l}\text { Typical military installations } \\
\text { chosen as experimental } \\
\text { units; Work closely with the } \\
\text { ministry of environment }\end{array}$ & $\mathrm{N} / \mathrm{A}$ & $\begin{array}{l}\text { State Environmental Policy following } \\
\text { European legislation (1993); "the } \\
\text { conception protection" for defence } \\
\text { (1996); pollution sources database for } \\
\text { for military Installations" project (2001) }\end{array}$ & $\begin{array}{l}\text { In 2001, a "pollution sources } \\
\text { database military installations } \\
\text { project began to develop in the } \\
\text { armed forces, as an outcome of } \\
\text { a nationwide program of } 1999\end{array}$ \\
\hline India & $\mathrm{N} / \mathrm{A}$ & Application required & $\begin{array}{l}\text { Military sector incorporated } \\
\text { the environmental protection } \\
\text { framework (1993) }\end{array}$ & $\mathrm{N} / \mathrm{A}$ & $\begin{array}{l}\text { Environmental strategies, policies and } \\
\text { management plans formulated, well- } \\
\text { controlled and publicly available }\end{array}$ & N/A \\
\hline
\end{tabular}




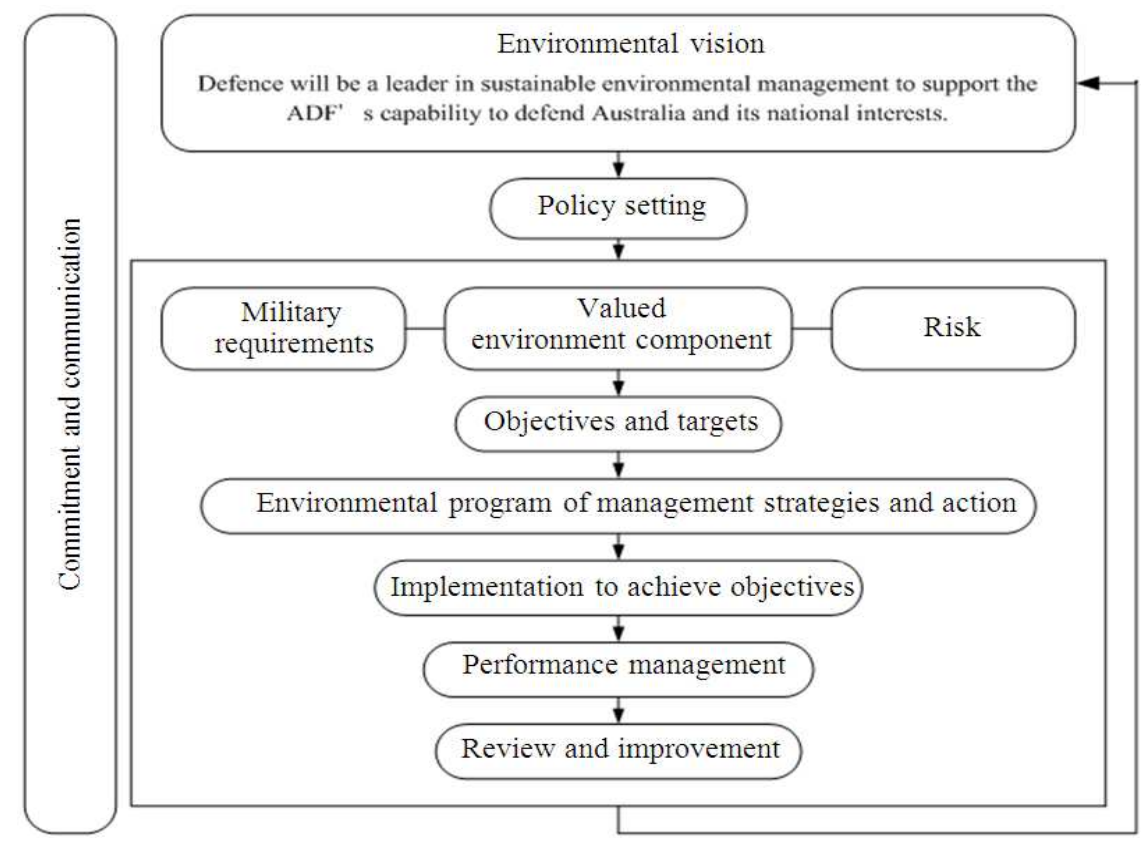

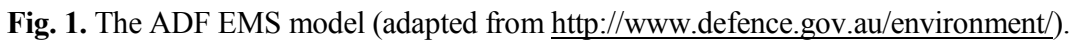

The ISO14001 defines it as "measurable results of an organization's management of its environmental aspects". Under the framework of an EMS, environmental outcomes can be measured in light of the organisation's “environmental policy, environmental objectives, environmental targets and other environmental performance requirements" (ISO, 2004). In other studies, environmental performance is measured by the extent to which there is compliance with legal requirements, reduction of environmental impacts and improvement in environmental efficiency (Rao, 2005; Ramos et al., 2009). However, whether an EMS results in improved environmental performance is still not clear (Lundberg et al., 2005).

The ISO14001 EMS allows an organisation to "evaluate environmental performance against policy, objectives and performance targets, while seeking performance improvements where appropriate" (Melnyk et al., 2003).

However, it merely presents the requirements and operational processes that an EMS-certified organisation should carry out, rather than providing definitive criteria for measuring improvement in environmental performance and EMS effectiveness (Edwards et al., 1999; Rondinelli and Vastag, 2000; Melnyk et al., 2003; Nawrocka and Parker, 2009). This was highlighted by Andrews et al. (1999): "ISO14001 does not prescribe substantive environmental performance standards, nor does it direct which of many possible environmental goals should be given priority. It does not prescribe the introduction of specific pollution-prevention or sustainability-related practices. It does not mandate how fast or how far 'continuous improvement' must proceed, nor even how quickly an organization must actually achieve compliance with environmental regulations". Thus the adoption of the ISO14001 will not guarantee optimal environmental performance: this depends on how effectively the EMS is implemented (Rondinelli and Vastage, 2000; Anton et al., 2004). Another concern is that the choice of study tools and research methods (quantitative, qualitative or a combination of the two) might lead to different processes and results in the evaluation of environmental performance (Nawrocka and Parker, 2009).

According to the findings of Nawrocka and Parker (2009), a successful EMS can be attributed to many internal and external factors in an organisation, such as its characteristics, management attitude, culture, policies and stakeholder participation. Various necessary features of an effective EMS have also been discussed (Chin et al., 1999; Gallagher et al., 1999; McDonach and Yaneske, 2002; Dawson, 2004; Lundberg et al., 2005); these are summarised as follows:

- Environmental commitment

- Covering all environmental matters

- Vigorous environmental management plans and strategies 
- Objectives and targets

- Identification of environmental impacts

- Incident response and technical support

- Documenting processes

- Environmental reporting, communication and transparency

- Follow-up measures (e.g., environmental monitoring and evaluation)

- Acceptance by all levels of the organisation and integrated into everyday management business

The above features are consistent with the ISO14001 standard. These can be used as references when assessing an EMS of an organisation.

\subsubsection{Methods of Evaluating an EMS}

Numerous studies using various assessment methodologies have been conducted to examine the motivations in and benefits of adopting the ISO14001 EMS, as well as to evaluate the effects of an EMS on an organisation's environmental performance (Andrews et al., 1999; Edwards et al., 1999; Maier and Vanstone, 2005; Potoski and Prakash, 2005). These studies cover organisations ranging from individual authorities to large clusters of facilities in various sectors, in both developed and developing countries.

One of the most significant studies was the pilot study Environmental Management Systems: Do They Improve Performance?, which aimed to clarify the EMS implementation processes and examine its effectiveness on a facility's environmental performance (Edwards et al., 2002; UNCCHDPP, 2003). Sponsored by the USA Environmental Protection Agency (EPA), the study involved 91 facilities across 17 States. These facilities were in both public and private sectors such as major manufacturing, electronics, multinational companies, food processing, chemicals, military sectors and wastewater treatment facilities (Andrews et al., 1999; UNCCHDPP, 2003). A Multi-State Working Group on the EMS was established by this study in 1996, responsible for monitoring and recording performance changes related to EMS implementation. In order to efficiently manage data and facilitate EMS evaluation, a database was developed in 1997, the National Database on Environmental Management Systems (NDEMS) (UNCCHDPP, 2003).

The research found that most participating facilities received considerable benefits from EMS adoption and implementation, including a decrease in environmental impacts, enhancement of employee environmental awareness and stakeholder relationships, promotion of documenting procedures and better evaluation of internal operations (Darnall et al., 2000; Freimann and Schwedes, 2000). This gives some indication of the effectiveness of an EMS.

The New Hampshire Department of Environmental Services (NHDES) joined this project in 1997. Five firms were involved in their study, with one being from the defence sector. This study mainly discussed EMS implementation regarding regulatory compliance (e.g., DES Compliance Assurance Response Policy), environmental audits in accordance with the EPA's Audit Policy, incentives for good environmental performance and cooperation with the National Performance Track Program and the DES Pollution Prevention Program (NHDES, 2002).

Another research team from the University of California conducted a study using extensive surveys and interviews to evaluate the effectiveness of an ISO14001 EMS in USA firms with a certified EMS, government sectors, NGOs and environmental auditors. Research issues were analysed mainly in terms of four implications: environmental; stakeholder; organisational; and legal. The companies investigated considered the EMS relatively beneficial, whereas most NGOs were suspicious about EMS effectiveness in promoting environmental performance, as also noted by Steger (2000).

Subsequently, several practical tools were developed for managers to facilitate EMS evaluation, such as the ISO Gap Analysis matrix (an ISO14001 Roadmap) and an environmental checklist (Edwards et al., 1999). The gap-analysis approach was also adopted by Rashed et al. (2008), using the Egyptian Minerals and Salts Company as a case study. Two kinds of tables were produced, a "checklist table" and a "questioner table", to compare the requirements of the ISO standard with the company's actual environmental performance. McDonach and Yaneske (2002) proposed a sustainability model to evaluate ISO14001 EMS implementation. Different kinds of conceptual methods applied to evaluate an organisation's sustainability were reviewed by Andrews et al. (1999). A number of relevant studies are listed together with their aims, methods and findings in Table 3.

Because of the difficulties inherent in developing a universal environmental performance evaluation framework, the majority of methods applied are investigative, such as interviews, questionnaire surveys, participating observations and case studies. Selfevaluation and conceptual measures are also common, with both qualitative and quantitative methods used (Rondinelli and Vastage, 2000; Sroufe, 2003; Anton et al., 2004; Rowland-Jones et al., 2005). Statistical tools are used for data analysis in some studies (Chin et al., 1999; Hui et al., 2001; Dahlstrom et al., 2003; Melnyk et al., 2003; Anton et al., 2004; Potoski and Prakash, 2005; Ann et al., 2006; Arimura et al., 2008; Hertin et al., 2008; Nawrocka and Parker, 2009). 
Xiao Hua Wang and Wen Wu / American Journal of Environmental Science 9 (2): 164-181, 2013

Table 3. A summary of studies on EMS evaluation

\begin{tabular}{|c|c|c|}
\hline Author(s) and time & Aim(s) of study & Study group \\
\hline Chin et al. (1999) & $\begin{array}{l}\text { Evaluate successful } \\
\text { factors and necessity } \\
\text { of the EMS implementation }\end{array}$ & $\begin{array}{l}\text { Hong kong manufacturing } \\
\text { facilities }\end{array}$ \\
\hline $\begin{array}{l}\text { Rondinelli and } \\
\text { Vastag (2000) }\end{array}$ & $\begin{array}{l}\text { Assess the impacts of the } \\
\text { ISO14001 EMS standard }\end{array}$ & $\begin{array}{l}\text { An aluminium plant } \\
\text { in South Carolina }\end{array}$ \\
\hline Steger (2000) & $\begin{array}{l}\text { Assess the EMS's } \\
\text { Impacts on } \\
\text { companies' business and } \\
\text { natural environment }\end{array}$ & $\begin{array}{l}\text { Some small-scale } \\
\text { EMS investigations } \\
\text { and two comprehensive } \\
\text { studies for Germany } \\
\text { and Austrian }\end{array}$ \\
\hline
\end{tabular}

Method(s)

Conclusion and comments

The Analytic Hierarchy Process (AHP) methodology;

Elements of the EMS implementation divided into several hierarchy levels, six evaluators chosen to compare elements f each level in pairs using nine-point scales; Data were collected through expert interviews; Normalized priority weights of each element decided through pair- wise comparisons with help of "Expert Choice"; The geometric mean method was applied to combine each evaluator's judgment of pair-wise comparisons to obtain relative importance of successful elements in the

In-depth case study; Four major aspects examined: employee awareness (environmental awareness training); operational fficiency (goals and benefits); managerial awareness (the EMS implementation; and improved management practices) ); an operational effectiveness (waste reduction and recycling); Data collected from program evaluation literature, archival material plant site visits, interviews of key environmental managers, concept mapping exercise involving 15 environmental management team members; A structured conceptualization" methodology applied: a sequence of concrete operationally defined steps that yields a conceptual representation of an evaluation result or idea domain through "concept mapping"”

companies' business and

Literature review of empirical studies

and Austrian

environmental ministries

The ISO14001 EMS was neither a panacea for solving all

environmental problems nor merely a label. Rather, it could
provide a "common sense guideline provide a "common sense guideline
for environmental management; for environmental manageme guarantee environmental performance improvements, it could bring managerial and behavioural impacts to promote environmental practices

Many companies reduced their pollution, promoted legal compliance; the EMS was considered as a powerful tool in environmental management; Enhance environmental goal setting, ecological priority consideration, integration other management systems and third-party auditing Waste reduction and management was considered to be the most significant improvement; Recommendations including clarifying environmental aspect identification, integrating with other management systems, increasing EMS-related knowledge and reinforcing follow-up management activities Benefits could be achieved through the EMS implementation the EMS with the ISO14001 organized by the
weightings Hong Kong weightings

29 questionnaire surveys based on AHP methods using nine-point scale; collected data transformed into normalized productivity using "Expert Choice" software

had positive effects their management

Case study; Telephone and face-to-face interviews

The ISO14001 EMS had beneficial effects on regulatory compliance managers' involvement, relationship with the public, environmental training market competitive strength, market competitive strength,

reporting

Emilsson and

Examine motivation of EMS

289 Swedish local adoption, the EMS
implementation, anticipated authorities

Nationwide survey; Posted questionnaires including both and actual outcomes

$\begin{array}{lll}\begin{array}{l}\text { Morrow and } \\ \text { Rondinelli (2002) }\end{array} & \begin{array}{l}\text { Examine motivation and } \\ \text { impacts of the EMS adoption }\end{array} & \begin{array}{l}\text { Small energy and gas } \\ \text { companies in Germany }\end{array} \\ \begin{array}{l}\text { Welch } \text { et al. } \\ (2002)\end{array} & \begin{array}{l}\text { Examine the ISO14001 } \\ \text { EMS adoption drivers; }\end{array} & \begin{array}{l}\text { Four of Japan private } \\ \text { sectors (chemical, } \\ \text { electronics electric } \\ \text { machinery and }\end{array} \\ & \begin{array}{l}\text { Find adoption differences } \\ \text { between first-stage, second- }\end{array} & \begin{array}{l}\text { electric power) } \\ \text { stage and non-adopters }\end{array} \\ \begin{array}{l}\text { Dahlstrom } \text { et al. } \\ (2003)\end{array} & \begin{array}{l}\text { Assess the relationship } \\ \text { between the EMS, operator } \\ \text { performance and enforcemen }\end{array} & \begin{array}{l}\text { More than 800 } \\ \text { production sites in } \\ \text { England and Wales } \\ \text { within the UK's }\end{array} \\ & \begin{array}{l}\text { action; assess whether the } \\ \text { EMS could be applied to } \\ \text { expand "risk-based regulation" }\end{array} & \begin{array}{l}\text { Integrated Pollution } \\ \text { Control regime }\end{array} \\ \text { Melnyk } \text { et al. } & \begin{array}{l}\text { Assess the EMS's impact on } \\ \text { corth American } \\ \text { (2003) }\end{array} & \begin{array}{l}\text { corporate environmental } \\ \text { manuacturing } \\ \text { industries }\end{array} \\ & \text { Performance } & \end{array}$

Literature review and few previous empirical studies; Five in-depth case studies

Questionnaire survey; A model established containing regulatory, , competitiveness, social responsibility and organization theory; Hypothesis testing and regression analysis

Survey; interviews with iso14001 certified sites, environment agency enforcement officers and the united kingdom accreditation service mostly subjective assessments Based on Operator Performance and Risk Appraisal (OPRA) database and the Environment Agency's enforcement database; Analyses of statistical variance (ANOVA tests) Self-reported measures; A multi-method research perspective incorporating case studies; pilot tests; interviews; questionnaire surveys; and regression analysis using STATA statistical tool; 11-point scale for respondents to those who not. assess environmental 11 ariables.

Most reported positive experiences from the EMS implementation some had no environmental changes; the useful tool in environmental useful tool in environmental performance improvements
Beneficial broadly, but hard to quantify; Not all expectations were quantify; Not all expectations were
met The majority of environmental met The majority of environment
performance improvements were performance improvem not related to the EMS
The ISO14001 EMS adoption did The ISO14001 EMS adoption did
not have clear causal relation with not have clear causal relation with
green activities, but was related to environmental action

The EMS achieved certain procedural aspects of environment management No evident relation between the EMS enforcement action and operator performance on non-compliance issues

Firms with an ISO14001 certified EMS usually had a better environmental performance than 
Xiao Hua Wang and Wen Wu / American Journal of Environmental Science 9 (2): 164-181, 2013

\begin{tabular}{|c|c|}
\hline Sroufe (2003) & $\begin{array}{l}\text { Examine direct and indirect } \\
\text { effects of the EMS on firms, } \\
\text { environmental management } \\
\text { and operation }\end{array}$ \\
\hline $\begin{array}{l}\text { Strachan et al. } \\
(2003)\end{array}$ & $\begin{array}{l}\text { Examine the ISO14001. } \\
\text { EMS adoption motivation, } \\
\text { implementation barriers } \\
\text { and benefits }\end{array}$ \\
\hline $\begin{array}{l}\text { Anton et al. } \\
\text { (2004) }\end{array}$ & $\begin{array}{l}\text { Examine the EMS } \\
\text { adoption motivation; } \\
\text { Explore the relation } \\
\text { between the EMS } \\
\text { quality and toxic } \\
\text { Release intensity }\end{array}$ \\
\hline $\begin{array}{l}\text { Remas project } \\
\text { Salmons } \\
(2004)\end{array}$ & $\begin{array}{l}\text { Explore the relationship } \\
\text { between the EMS, } \\
\text { operator performance } \\
\text { and environmental }\end{array}$ \\
\hline $\begin{array}{l}\text { Cheesbrough } \\
\text { (2006) }\end{array}$ & Outcomes \\
\hline $\begin{array}{l}\text { Hughey et al. } \\
(2005)\end{array}$ & $\begin{array}{l}\text { ISO14001 driving } \\
\text { forces, benefits } \\
\text { evaluation }\end{array}$ \\
\hline $\begin{array}{l}\text { Lundberg et al. } \\
\text { (2005) }\end{array}$ & $\begin{array}{l}\text { Detect rail operation, } \\
\text { environmental activities, } \\
\text { environmental aspects and } \\
\text { impacts and current follow- } \\
\text { up actions; examine the } \\
\text { EMS and EPE application }\end{array}$ \\
\hline $\begin{array}{l}\text { Maier and } \\
\text { Vanstone (2005) }\end{array}$ & $\begin{array}{l}\text { Explore the relationship } \\
\text { between the EMS and } \\
\text { environmental performance } \\
\text { over a three-year period }\end{array}$ \\
\hline
\end{tabular}

$\begin{array}{ll}\begin{array}{l}\text { USA manufacturing } \\ \text { companies }\end{array} & \begin{array}{l}\text { Field study; Survey (the largest survey conducted in } \\ \text { manufacturing field in USA) Conceptual model established } \\ \text { including EMS, environmental design, recycling and waste } \\ \text { practices and operation performance; structural equation } \\ \text { modelling elliptical reweighted least squares; confirmatory } \\ \text { factor analysis }\end{array} \\ \begin{array}{l}\text { Review EMS-related literature; } \\ \text { Eight UK oil and gas } \\ \text { companies in the } \\ \text { Snited Kingdom }\end{array} & \\ \text { Continental Shelf } & \end{array}$

Positive relationship between the
EMS, environmental performance
and operation management;
A list of measurement indicators
corresponding to the conceptual
model was developed
The majority considered improved
environmental performance and
environmental awareness was
achieved; the EMS was a useful
deserved broader adoption in oil
and gas industry; reinforcement
of social responsibility and
environmental management.
The EMS reduced toxic emission,
particularly in higher pollution
intensity plants, reduced on-site
releases and off-site transfers
No direct relation between
influenced factors of the EMS
quality and toxic release intensity
Significant positive relation
between the ISO14001 EMS
adoption and operator performance;
No strong evidence about improved
operator performance and better
environmental outcomes

USA Standard and poor Survey conducted by the investor research responsibility SandP) 500 firms under centre; Establishment of conceptual and empirical the Corporate Environmental Profile Directories framework, including 13 environmental management practices as evaluation indicators; Count data from the Toxics Release Inventory (TRI); quantile regression analysis (e.g., poison and negative binomial models, instrumental variables methods and Generalized Methods of Moments) $\begin{array}{ll}\text { Business and industry } & \text { Questionnaire survey; emission standards were in accordance } \\ \text { companies around } & \text { with "best available techniques" under the EU's integrated }\end{array}$ EU Member States; A three-year project pollution prevention and

Control directive; quality-control audits (e.g., site visits, cross reference to regulatory inspectors, data website);

Mathematical model, hypothesis testing, regression analysis; Operator performance was measured by a facility's EMA; scores for environmental outcome, EP scores

15 wine companies in Qualitative survey; Questionnaire is consistent with triple bottom Line reporting sustainability guidelines, including environmental aspects and quality, EMS implementation,
management influences; Interview-based questions, management influences; Interview-based face-to-face and telephon
Participant observations;

Swedish National Rail Administration; Railway departments of different countries

More than 800 highenvironmental-impact companies in the FTSE all world developed index (including global medium-

questionnaire surveys; unstructured interviews and large- size companies

Worldwide survey and publicly available data; Assess the EMS's quality using the basic EMS elements as indicators; UK Environment Agency treated the EMS using risk-based approach through the OPRA scheme. Companies with the EMS could get additional awards in the OPRA scoring system Five categories for environmental performance improvement given according to individual weighted scores

\begin{tabular}{|c|c|c|}
\hline $\begin{array}{l}\text { Potoski and } \\
\text { Prakash (2005) }\end{array}$ & $\begin{array}{l}\text { Investigate whether } \\
\text { the ISO14001 EMS } \\
\text { could improve } \\
\text { environmental performance }\end{array}$ & $\begin{array}{l}\text { More than } 3000 \text { facil } \\
\text { considered as 'major } \\
\text { under the USA clean }\end{array}$ \\
\hline $\begin{array}{l}\text { Ann et al. } \\
\text { (2006) }\end{array}$ & $\begin{array}{l}\text { Investigate the EMS impacts } \\
\text { on firm environmental } \\
\text { performance and customers' } \\
\text { satisfaction }\end{array}$ & $\begin{array}{l}\text { ISO14001 certified fil } \\
\text { in the Federation of } \\
\text { Malaysian Manufactu }\end{array}$ \\
\hline $\begin{array}{l}\text { Schylander and } \\
\text { Martinuzzi (2007) }\end{array}$ & $\begin{array}{l}\text { Examine driving forces, } \\
\text { expectation and actuality of } \\
\text { the EMS implementation, } \\
\text { environmental impacts and } \\
\text { effects, integration with } \\
\text { other management systems }\end{array}$ & $\begin{array}{l}\text { More than } 500 \text { organ } \\
\text { with the ISO14001 } \\
\text { EMS in Austria }\end{array}$ \\
\hline $\begin{array}{l}\text { Arimura et al. } \\
(2008)\end{array}$ & $\begin{array}{l}\text { Evaluate the ISO14001 EMS } \\
\text { implementation and } \\
\text { environmental performance } \\
\text { changes }\end{array}$ & $\begin{array}{l}\text { Japan manufacturing } \\
\text { facilities }\end{array}$ \\
\hline $\begin{array}{l}\text { Hertin et al. } \\
\text { (2008) }\end{array}$ & $\begin{array}{l}\text { Evaluate the EMS's } \\
\text { impacts on companies } \\
\text { eco-efficiency }\end{array}$ & $\begin{array}{l}\text { European companies } \\
\text { in five industrial } \\
\text { sectors }\end{array}$ \\
\hline
\end{tabular}

Questionnaire survey; Japanese facility-level data obtained from the OECD survey; Application of econometric model; Establishment of statistical connection between different parameters to examine environmental performance Review of key studies on connection between the EMS and environmental performance; Large dataset from the Measuring Environmental Industry (MEPI) program, which incorporated 15000 environmental performance data points from 274 companies of six manufacturing sectors in six EU countries; Three independent instruments statistical tools (simple regression, Jaggi-Freedman indices, "trend differences" approach)

Mail survey;

Hypothesis testing and Pearson product-moment correlation

Calling for integrated environmental management and sustainable developments

EMS was broadly used; EPE and environmental performance indicators were relatively new issues and should be developed; Demand of integrated environmental management The majority had the EMS in place Some environmental performance improvements were reported; A positive correlation between the EMS quality and environmental performance improvements;

Demand of greater environmental reporting and quantitative data disclosure

Firms with the ISO14001 certified EMS reduced pollution emissions; Demands of efficient monitoring, and sanctions, third-party auditing and information disclosure Positive impacts reported and enhanced corporate image" was considered to be the strongest impact; Cooperation between firms, government and communities The ISO14001 EMS could reduce environmental impacts, especially in waste field; The ISO14001 EMS would be one of the most effective methods to improve environmental performance

Environmental regulation was related to the ISO14001 EMS effectiveness

No obvious evidence about the EMS's positive impacts on facilities environmental performance; Implication of social and soft policy 
The majority of qualitative data is obtained from surveys, interviews (structured, semi-structured and open-ended) and in-depth case studies. Questionnaires and interviews usually use a ranking or Likert scale. Quantitative methods have also been used in numerous long-term research projects (e.g., the NDEMS program and Remas project). A combination of qualitative and quantitative methods has been adopted by some researchers (Dahlstrom et al., 2003; Melnyk et al., 2003; Sroufe, 2003; Anton et al., 2004).

These studies reveal that presently there is no widely agreed methodology for evaluating EMS effectiveness (Hertin et al., 2008). A case-by-case approach is considered to be acceptable as long as evidence can be found to provide support for the evaluation of the relevant EMS. The majority of the findings conclude that there is a positive correlation between an EMS and improved environmental performance (Edwards et al., 1999; Ann et al., 2006; Rashed et al., 2008), although some studies find no clear relationship (Hughey et al., 2005; Rowland-Jones et al., 2005; Hertin et al., 2008; Nawrocka and Parker, 2009).

In defence sectors, work is beginning on the evaluation of military EMSs with the aim of greening military strategies. Examples include the NATO-CCMS and Dartmoor Training Area cases have already been described. These examples provide useful background information for conducting the evaluation of a militaryrelated EMS in future, examining connections between the effects of an EMS and the environmental performance of military activities.

In order to evaluate EMS effectiveness, the use of a supplementary instrument, an indicator framework comprising a set of complementary and objective indicators, has been suggested (Bowers and Cornish, 2000; Freimann and Schwedes, 2000; Kolk and Mauser, 2002; Dahlstrom et al., 2003; Lundberg et al., 2005). Dahlstrom et al. (2003) also noted that objective indicators for environmental performance measurement should be developed.

Many studies reviewed in this study have proposed various environmental indicator sets to assist in EMS evaluation (Edwards et al., 1999; Sroufe, 2003; UNCCHDPP, 2003). Ramos et al. (2007a) provided a comprehensive review of environmental indicator initiatives relevant to defence sectors, citing initial work on estimating EMS effectiveness (Dawson, 2004; Viegas, 2005; Ramos et al., 2007a). Indicator related issues are not the scope of this review, which have been discussed by Wu and Wang (2011) and Wu (2012).

\section{CONCLUSION}

The environmental management, especially in military activities, has been widely recognised as important by a large number of researchers and practitioners. Due to the complexity of defence operations, environment-related issues "need to be addressed in a systematic way" (Diecidue, 2008), for example, with the help of the ISO14001 EMS, one of the internationally best-known environmental management tools. As discussed in this study, there are no significant differences in the EMS adoption, structure and implementation between different countries and defence sectors. In any case, the key point is to examine how effective an EMS is in environmental management, rather than whether there is an EMS or not (Bowers and Cornish, 2000; Dawson, 2004). Based on a literature review, this study has contributed to an understanding of EMS implementation and evaluation in global defence sectors.

There is a wide range of application of an EMS all over the world. As illustrated in this review, there is no "one-size-fits-all" method (NOAACSC, 2007) for evaluation and analysis of an EMS (Rowland-Jones et al., 2005). An EMS is a complicated system, requiring a number of criteria to evaluate its success that depend on different specific factors (e.g., organisational features, environment and management objectives). However, there is an absence of absolute environmental performance requirements specified in the ISO14001 standard (Andrews et al., 1999; Rondinelli and Vastag, 2000; Lundberg et al., 2005; Nawrocka and Parker, 2009). Therefore, it is difficult to accurately assess an EMS in a quantitative way (e.g., by calculating a final score), especially for the environmental management of military activities.

There have been many different methods used in previous studies to assess the EMS effectiveness, both quantitative and qualitative. Nawrocka and Parker (2009) noted that one significant difficulty of quantitative approach was obtaining high-quality quantitative data. Furthermore, measuring environmental performance, especially quantitatively, is a widely recognised challenge in the field of environmental management and EMS implementation (Rowland-Jones et al., 2005; Hertin et al., 2008). Both quantitative and qualitative methods have advantages and disadvantages. It is important to choose methods cautiously and appropriately, because each organisation has its own characteristics. Case-by-case analyses are required, considering such issues as the context (e.g., political, 
environmental and economic), features of the study area, objectives and methods and management capabilities (Edwards et al., 1997; NOAACSC, 2007; Arimura et al., 2008; Broderick, 2008; Zutshi et al., 2008; Lennox et al., 2011).

As can be seen from this review, although relevant studies have been conducted, they still do not provide sufficient understanding of an EMS's effect on policy formulation, environmental performance and social influence, especially in defence sectors. Knowledge gaps between the EMS efforts and improved environmental performance need to be identified; further research on how to evaluate EMS effectiveness is therefore needed (Gallagher et al., 1999; Freimann and Schwedes, 2000; Lundberg et al., 2005; Rashed et al., 2008). For example, it is necessary to establish Environmental Performance Indicators (EPIs) and make them publicly available, in order to clarify the relationship between EMS implementation and environmental performance (Steger, 2000; Strachan et al., 2003; Rowland-Jones et al., 2005; Cheesbrough, 2006; Schylander and Martinuzzi, 2007).

Rather than self-assessment by managers (Ramos and Melo 2005; 2006; Ramos et al., 2007a; 2007b; Rowland-Jones et al., 2005), an independent evaluation through the collection of various data and information from different viewpoints has also been suggested, in order to obtain an integrated analysis (Greenwood, 2001; Beger et al., 2005; Burger et al., 2005). The internal assessment method is considered not comprehensive and objective enough; internal evaluations tend to give positive assessments (Rowland-Jones et al., 2005; Hertin et al., 2008; Nawrocka and Parker, 2009). Therefore, a "third-party evaluation" approach is important; it could "prevent bias, omission of important or "bad news' events and improve credibility" (Greenwood, 2001). Additionally, it is important to collect various scientific data and high-quality information (e.g., reliable, verifiable, complete and comparable), improve environmental impact assessment, promote continuous environmental monitoring and reporting, in order to facilitate implementation and evaluation of an EMS (SASNZ, 2000; Burger et al., 2005).

This stduy has furthered the knowledge of EMS application and evaluation practices and provided a reference for policy making and environmental management of an organisation. Environmental management is a changing process; the EMS implementation demonstrates an organisation's ability to respond to changes, leading to continuous improvement (Perron et al., 2006). As shown in this review, it is difficult to define a single way to evaluate an EMS; it should be revised and updated to respond to the changing situation (West et al., 2006). Regular reviews will ensure effective interaction between the EMS modules. In a word, organisations need to find out the best way to use an EMS effectively and to gather convincing evidence to evaluate an EMS.

\section{ACKNOWLEDGMENT}

This is a publication of the Sino-Australian Research Centre for Coastal Management, paper number 11. Wen $\mathrm{Wu}$ has been supported by the China Scholarship Council and University of New South Wales (UNSW) Top-up Scholarship for her PhD study in UNSW. Wen $\mathrm{Wu}$ is also sponsored by the UNSW Canberra Publication Fellowship. Dr David Paull's co-supervision to and Ms Julie Kesby's editorial and literature support on $\mathrm{Wu}$ 's $\mathrm{PhD}$ thesis is acknowledged.

\section{REFERENCES}

Anderson, B., M. Bryce, J. Theobald, J.Oakley and T. Wilkes et al., 2007. Habitat management for tanks a Tuans: Evolving approaches at Puckapunyal military area. Ecol. Manage. Restorat., 8: 11-25. DOI: 10.1111/j.1442-8903.2007.00327.x

Andrews, R.N.L., N. Darnall and D.R. Gallagher, 1999. Environmental management systems: A sustainable strategy for a sustainable world? Proceedings of the 8th International Conference of the Greening of Industry Network, "Sustainability: Ways of Knowing, Ways of Acting”, Nov. 14-17, University of North Carolina at Chapel Hill, North Carolina, pp: 1-15.

Ann, G.E., S. Zailani and N.A. Wahid, 2006. A study on the impact of Environmental Management System (EMS) certification towards firms' performance in Malaysia. Manage. Environ. Q. An. Int. J., 17: 7393. DOI: $10.1108 / 14777830610639459$

Anton, W.R.Q., G. Deltas and M. Khanna, 2004. Incentives for environmental self-regulation and implications for environmental performance. J. Environ. Econ. Manage., 48: 632-654. DOI: 10.1016/j.jeem.2003.06.003

Arimura, T.H., A. Hibiki and H. Katayama, 2008. Is a voluntary approach an effective environmental policy instrument? A case for environmental management systems. J. Environ. Econ. Manage., 55: 281-295. DOI: 10.1016/j.jeem.2007.09.002

Ayers, P.D., 1994. Environmental damage from tracked vehicle operation. J. Terramechanics, 31: 173-183. DOI: 10.1016/0022-4898(94)90014-0 
Beeby, R., 2008. Defence wants free rein on training. Canberra Times.

Beger, M., A.R. Harborne, T.P. Dacles, J. Solandt and G.L. Ledesma, 2005. A framework of lessons learned from community-based marine reserves and its effectiveness in guiding a new coastal management initiative in the Philippines. Environ. Manage., 34: 786-801. DOI: $10.1007 / \mathrm{s} 00267-004-0149-\mathrm{z}$

Bioce, L.P., 2006. Defense and conservation: Compatible missions. Endangered Species Bull., 31: 4-7.

Bowers, D.P. and S.P. Cornish, 2000. Environmental management: Weighing up Environmental Performance Evaluation (EPE). ISO Bull.

Broderick, K., 2008. Adaptive management for water quality improvement in the Great Barrier Reef catchments: Learning on the edge. Geographical Res., 46: 303-313. DOI: 10.1111/j.17455871.2008.00525.x.

Burger, J., M. Gochfeld, D.S. Kosson, C.W. Powers and B. Friedlander et al., 2005. Science, policy and stakeholder: Developing a consensus science plan for Amchitka Island, Aleutians, Alaska. Environ. Manage., 35: 557-568. DOI: 10.1007/s00267-0040126-6

Cheesbrough, M., 2006. The results of the remas projectremas layman's report.

Chin, K.S., S. Chiu and V.M.R. Tummala, 1999. An evaluation of success factors using the AHP to implement ISO14001-based EMS. Int. J. Q. Reliab. Manage., 16: 341-361. DOI: 10.1108/02656719910248226

Cuddy, S.M., P. Laut, J.R. Davis, P.A. Whigham and J. Goodspeed et al., 1990. Modelling the environmental effects of training on a major Australian army base. Math. Comput. Simul., 32: 83-88. DOI: 10.1016/0378-4754(90)90219-9

Dahlstrom, K., C. Howes, P. Leinster and J. Skea, 2003. Environmental management systems and company performance: Assessing the case for extending riskbased regulation. Eur. Environ., 13: 187-203. DOI: 10.1002/eet.323

Darnall, N., D.R. Gallagher, R.N.L. Andrews and D. Amaral, 2000. Environmental management systems: Opportunities for improved environmental and business strategy? Environ. Q. Manage., 9: 1-9. DOI: $\quad 10.1002 / 1520-6483(200021) 9: 3<1:: A I D-$ TQEM1>3.0.CO;2-L

Dawson, M., 2004. Environmental Management Systems (EMS) in the Military Sector-Promoting Broader Implementation. In: In: Defense and the Environment: Effective Scientific Communication, Mahutova, K., J.J. Barich and R.A. Kreizenbeck (Eds.), Springer, Dordrecht, ISBN-10: 1402020821, pp: 75-83.
DD, 2000. ISO14001 Environmental management systems pilot study final report April 2000.

DD, 2002. Defense Environmental Quality Program Annual Report to Congress-Fiscal Year 2002Environmental Management Systems.

DD, 2003. Defence public environment report. Department of Defence, Canberra, pp: 33.

DD, 2005. Review of Management Arrangements for the Great Barrier Reef Marine Park. Department of Defence Public Submission.

DD, 2007. Defence Environmental Policy. Defence Support Group. Department of Defence.

DD, 2009. State of the environment report for Shoalwater Bay Training Area 2008. Department of Defence, Russell, ACT.

Diecidue, T., 2008. Military-to-military collaboration on environmental management: A framework for strategic information, education and communication. Project Performance Corporation, Virginia, USA.

Diersing, V.E., R.B. Shaw and D.J. Tazik, 1992. US army Land Condition-Trend Analysis (LCTA) program. Environ. Manage., 16: 405-414. DOI: 10.1007/BF02400080

DNPA, 2005. Dartmoor and its military use: 2005 status. Dartmoor National Park Authority.

Doxford, D. and J. Savege, 1995. The proposed development of Otterburn Military Training Area in Northumberland National Park: A national perspective. J. Environ. Plann. Manage., 38: 551560. DOI: $10.1080 / 09640569512814$

Doxford, D. and T. Hill, 1998. Land use for military training in the UK: The current situation, likely developments and possible alternatives. J. Environ. Plann. Manage, 41: 279-297. DOI: $10.1080 / 09640569811597$

DSEWPaC, 2008. Model environmental management system for Australian Government agencies. Department of Sustainability, Environment, Water, Population and Communities.

Durant, R.F., 2007. The Greening of the U.S. Military: Environmental Policy, National Security and Organizational Change. 1st Edn., Georgetown University Press, Washington D.C., ISBN-10: 1589011538, pp: 298.

Edwards, B., J. Gravender, A. Killmer, G. Schenke and M. Willis, 1999. The effectiveness of ISO 14001 in the United States. A Group Project Thesis, University of California. 
Edwards, D., J D. Amaral and R. Andrews, 2002. EMSs and performance change: What happens? Proceedings of the MSWG Moving to Higher Environmental Performance Using EMS Workshop, Jun. 3-3, University of North Carolina at Chapel Hill, Orlando, Florida, pp: 50.

Edwards, S.D., P.J.S. Jones and D.E. Nowell, 1997. Participation in coastal zone management initiatives: A review and analysis of examples from the UK. Ocean Coastal Manage., 36: 143-165. DOI: 10.1016/S0964-5691(97)00011-2

Emilsson, S. and O. Hjelm, 2002. Implementation of standardised environmental management systems in Swedish local authorities: Reasons, expectations and outcomes. Environ. Sci. Policy, 5: 443-448. DOI: 10.1016/S1462-9011(02)00090-4

Freimann, J. and R. Schwedes, 2000. EMAS experiences in German companies: A survey on empirical studies. Eco-Manage. Audit., 7: 99-105. DOI: 10.1002/1099-0925(200009)7:3<99::AID-

EMA135>3.0.CO;2-X.

Frost, R., 2010. ISO $9001 \times 1000000$ latest edition of the ISO Survey. ISO Focus.

Gallagher, D.R., N. Darnall and R.N.L. Andrews, 1999. International standards for environmental management systems: A future promise for environmental policy? Proceedings of the 21st Annual Research Conference for the Association for Public Policy Analysis and Management Fall Conference: "Public Policy Analysis and Management: Global and Comparative Perspectives", Nov. 4-6, University of North Carolina at Chapel Hill, NC, Washington, D.C.

Godschalk, C.S.K., 2007. Green Soldiering.

Greenwood, M.R., 2001. Community as a Stakeholder: Focusing on Corporate Social and Environmental Reporting. 1st Edn., Monash University, Australia, pp: 15.

Hale, M., 1995. Training for environmental technologies and environmental management. J. Cleaner Product. 3: 19-23. DOI: 10.1016/0959-6526(95)00060-R

Herl, B.K., W.W. Doe and D.S. Jones, 2005. Use of military training doctrine to predict patterns of maneuver disturbance on the landscape. I. Theory and methodology. J. Terramechanics, 42: 353-371. DOI: $10.1016 /$ j.jterra.2004.10.009

Hertin, J., F. Berkhout, M. Wagner and D. Tyteca, 2008. Are EMS environmentally effective? The link between environmental management systems and environmental performance in European companies. J. Environ. Plann. Manage., 51: 259-283. DOI: $10.1080 / 09640560701865040$
Hirst, R.A., R.F. Pywell and P.D. Putwain, 2000. Assessing habitat disturbance using an historical perspective: The case of Salisbury Plain military training area. J. Environ. Manage., 60: 181-193. DOI: $10.1006 /$ jema.2000.0356

Hughey, K.F.D., S.V. Tait and M.J. O’Connell, 2005. Qualitative evaluation of three 'environmental management systems' in the New Zealand wine industry. J. Cleaner Product., 13: 1175-1187. DOI: 10.1016/j.jclepro.2004.07.002

Hui, I.K., A.H.S. Chan and K.F. Pun, 2001. A study of the environmental management system implementation practices. J. Cleaner Product., 9: 269-276. DOI: 10.1016/S0959-6526(00)00061-5

ISO, 2004. ISO 14001:2004, Environmental Management Systems-Requirements with guidance for use. International Organization for Standardization, Switzerland.

ISO, 2007. The ISO Survey-2007. International Organization for Standardization, Switzerland.

Klassen, R.D. and C.P. Mclaughlin, 1996. The impact of environmental management on firm performance. Manage. Sci., 42: 1199-1214. DOI: 10.1287/mnsc.42.8.1199

Kolk, A. and A. Mauser, 2002. The evolution of environmental management: From stage models to performance evaluation. Bus. Strategy Environ., 11: 14-31. DOI: $10.1002 /$ bse. 316

Kreizenbeck, R.A., 2004. Environmental Aspects of Managing of Natural Resource Assets Within the Military Sector. In: Defense and the Environment: Effective Scientific Communication, Mahutova, K., J.J. Barich and R.A. Kreizenbeck (Eds.), Springer, Dordrecht, ISBN-10: 1402020821, pp: 15-19.

Kusnir, L., 2004. Environmental Policy in the Slovak Armed Forces, Environmental Management System as a Challenge for the Future. In: Defense and the Environment: Effective Scientific Communication, Mahutova, K., J.J. Barich and R.A. Kreizenbeck (Eds.), Springer, Dordrecht, ISBN-10: 1402020821, pp: 71-74.

Latham, R.E., D. Zercher and P. McElhenny, 2007. The role of disturbance in habitat restoration and management for the eastern regal fritillary (Speyeria idalia idalia) at a military installation in Pennsylvania. Ecol. Restorat., 25: 103-111. DOI: 10.3368/er.25.2.103

Lehman, R.N., K. Steenhof, M.N. Kochert and L.B. Carpenter, 1999. Effects of military training activities on shrub-steppe raptors in southwestern Idaho, USA. Environ. Manage., 23: 409-417. DOI: $10.1007 / \mathrm{s} 002679900196$ 
Leis, S.A., D.M. Engle, J.R.D.M. Leslie and J.S. Fehmi, 2005. Effects of short- and long-term disturbance resulting from military maneuvers on vegetation and soils in a mixed prairie area. Environ. Manage., 36: 849-861. DOI: 10.1007/s00267-004-0373-6

Leis, S.A., J.R. Leslie D.M. Engl and J.S. Fehmi, 2008. Small mammals as indicators of short-term and long-term disturbance in mixed prairie. Environ. Monit. Assess., 137: 75-84. PMID: 17458511

Leitmann, J., 1998. Policy and practice options for managing protected areas: Lessons from international experience. J. Environ. Plann. Manage., 41: 129-144. DOI: 10.1080/09640569811830

Lennox, J., W. Proctor and S. Russell, 2011. Structuring stakeholder participation in New Zealand's water resource governance. Ecol. Econ., 70: 1381-1394. DOI: 10.1016/j.ecolecon.2011.02.015

Linkov, I. and A.B. Ramadan, 2004. Comparative Risk Assessment and Environmental Decision Making. 1st Edn., Springer, Netherlands, Dordrecht, ISBN10: 1402018959 , pp: 436.

Lundberg, K., B. Balfors and L. Folkeson, 2005. Environmental management systems in rail operation and maintenance: Current practice and potential improvements. J. Environ. Assess. Pol. Manage., 7: 433-456.

Maier, S. and K. Vanstone, 2005. Do good environmental management systems lead to good environmental performance? Ethical Investment Research Services (EIRIS) Research Briefing, pp: 112.

McDonach, K. and P.P. Yaneske, 2002. Environmental management systems and sustainable development. Environmentalist, 22: 217-226. DOI: 10.1023/A:1016523611067

Mehta, J.N. and S.R. Kellert, 1998. Local attitudes toward community-based conservation policy and programmes in Nepal: A case study in the MakaluBarun Conservation Area. Environ. Conservation, 25: 320-333.

Melnyk, S.A., R.P. Sroufe and R. Calantone, 2003. Assessing the impact of environmental management systems on corporate and environmental performance. J. Operat. Manage., 21: 329-351. DOI: 10.1016/S0272-6963(02)00109-2

Mendoza, G.A., A.B. Anderson and G.Z. Gertner, 2002. Integrating multi-criteria analysis and GIS for land condition assessment: Part I-Evaluation and restoration of military training area. J. Geographic Inform. Decision Anal., 6: 1-16.
Moore, R.T., 2004. A corporate EMS for the UK Ministry of Defence. In: In: Defense and the Environment: Effective Scientific Communication, Mahutova, K., J.J. Barich and R.A. Kreizenbeck (Eds.), Springer, Dordrecht, ISBN-10: 1402020821, pp: 85-89.

Morrow, D. and D. Rondinelli, 2002. Adopting corporate environmental management systems: Motivations and results of ISO14001 and EMAS certification. Eur. Manage. J., 20: 159-171. DOI: 10.1016/S02632373(02)00026-9

NATO-CCMS, 2000. Pilot study on environmental management systems in the military sector.

Nawrocka, D. and T. Parker, 2009. Finding the connection: Environmental management systems and environmental performance. J. Cleaner Product., 17: 601-607. DOI: 10.1016/j.jclepro.2008.10.003

NHDES, 2002. Research into the effectiveness of environmental management systems. US Environmental Protection Agency, Region I, New England.

NOAACSC, 2007. Introduction to stakeholder participation, social science tools for coastal programs. NOAA Coastal Services Center, Charleston, SC., pp: 1-15.

Perron, G.M., R.P. Cote and J.F. Duffy, 2006. Improving environmental awareness training in business. J. Cleaner Product., 14: 551-562. DOI: 10.1016/j.jclepro.2005.07.006

Potoski, M. and A. Prakash, 2005. Covenants with weak swords: ISO14001 and facilities' environmental performance. J. Policy Anal. Manage., 24: 745-769. DOI: $10.1002 /$ pam. 20136

Ramos, T.B. and J.J. Melo, 2005. Environmental management practices in the defence sector: Assessment of the Portuguese military's environmental profile. J. Cleaner Product., 13: 1117 1130. DOI: $10.1016 /$ j.jclepro.2004.05.003

Ramos, T.B. and J.J. Melo, 2006. Developing and implementing an environmental performance index for the Portuguese military. Bus. Strategy Environ., 15: 71-86. DOI: $10.1002 /$ bse. 440

Ramos, T.B., I. Alves, R. Subtil and J.J. de Melo, 2009. The state of environmental performance evaluation in the public sector: The case of the Portuguese defence sector. J. Cleaner Product., 17: 36-52. DOI: 10.1016/j.jclepro.2008.02.009

Ramos, T.B., I. Alves, R. Subtil and J.J. Melo, 2007a. Environmental performance policy indicators for the public sector: The case of the defence sector. J. Environ. Manage., 82: 410-432. DOI: 10.1016/j.jenvman.2005.12.020 
Ramos, T.B., I. Alves, R. Subtil and J.J. Melo, 2007 b. Environmental pressures and impacts of public sector organizations: The case of the Portuguese military. Progress Indus. Ecol.: Int. J., 4: 363-381. DOI: 10.1504/PIE.2007.015617

Rao, N.H., 2005. Environmental management: Relevance and implications for management of defence installations for sustainability. Curr. Sci., 88: 1753-1758.

Rashed, I.M., E.A.S. Hasaneen, M. Edward and E.A. Dwagi, 2008. Environmental management system as a tool for improving the environmental performance (case study). J. Applied Sci. Res., 4: 383-390.

Reed, M.S., 2008. Stakeholder participation for environmental management: A literature review. Biol. Conservation 141: 2417-2431. DOI: 10.1016/j.biocon.2008.07.014

Rondinelli, D. and G. Vastag, 2000. Panacea, common sense, or just a label? The value of ISO14001 environmental management systems. Eur. Manage. J., 18: 499-510. DOI: 10.1016/S02632373(00)00039-6

Rowland-Jones, R., M. Pryde and M. Cresser, 2005. An evaluation of current environmental management systems as indicators of environmental performance. Manage. Environ. Q.: Int. J., 16: 211-219. DOI: 10.1108/14777830510591642

RPSHSE, 2005. External audit of Dartmoor Training Area's Environmental Management System Final Report Impact Assessment, Gap Analysis and Recommendations for Improvement. RPS Health, Safety and Environment, London, pp: 56.

Salmons, R., 2004. REMAS analysis of initial sample data for the United Kingdom. Environment Group, Policy Studies Institute.

SASNZ, 2000. AS/NZS ISO14031:2000 Environmental management systems Environmental performance evaluation Guidelines, Standards Australia, Australia.

Schylander, E. and A. Martinuzzi, 2007. ISO 14001experiences, effects and future challenges: A national study in Austria. Bus. Strat. Environ., 16: 133-147. DOI: $10.1002 /$ bse.473

Scott, B., J. McMaster and N. Baker, 2000. Environmental brief Shoalwater Bay Training Area January to December, mega brief No.4. Australian Oceanographic Data Centre, Potts Point.

Sinclair, R. and R. Tschirhart, 2001. Army Environmental Policy and ISO 14001. Federal Facilities Environ. J., 12: 53-65. DOI: 10.1002/ffej.1005
Smith, M.A., M.G. Turner and D.H. Rusch, 2002. The effect of military training activity on eastern lupine and the karner blue butterfly at fort McCoy, Wisconsin, USA. Environ. Manage., 29: 102-115. DOI: $10.1007 / \mathrm{s} 00267-001-0044-9$

Sroufe, R., 2003. Effects of environmental management systems on environmental management practices and operations. Product. Operat. Manage., 12: 416431. DOI: 10.1111/j.1937-5956.2003.tb00212.x

Steger, U., 2000. Environmental management systems: Empirical evidence and further perspective. Eur. Manage. J., 18: 23-37. DOI: 10.1016/S02632373(99)00066-3

Strachan, P.A., I.M. Sinclair and D. Lal, 2003. Managing ISO14001 implementation in the United Kingdom Continental Shelf (UKCS). Corporate Soc. Responsib. Environ. Manage., 10: 50-63. DOI: $10.1002 /$ csr.29

UNCCHDPP, 2003. Environmental Management Systems: Do they Improve Performance? Project final report. University of North Carolina at Chapel Hill, Chapel Hill, N.C.

Viegas, M., 2005. Environmental performance evaluation ISO14031:1999 and the future. ISO14001 ISO TC 207 Plenary, Madrid.

Wang, G., G. Gertner, H. Howard and A. Anderson, 2008. Optimal spatial resolution for collection of ground data and multi-sensor image mapping of a soil erosion cover factor. J. Environ. Manage., 88: 1088-1098. DOI:10.1016/j.jenvman.2007.05.014

Warren, S.D., S.W. Holbrook, D.A. Dale, N.L. Whelan and M. Elyn et al., 2007. Biodiversity and the heterogeneous disturbance regime on military training lands. Restorat. Ecol., 15: 606-612. DOI: 10.1111/j.1526-100X.2007.00272.x

Warren, S.D., V.E. Diersing, P.J. Thompson and W.D. Goran, 1989. An erosion-based land classification system for military installations. Environ. Manage., 13: 251-257. DOI: $10.1002 /$ ffej. 10019

Welch, E.W., Y. Mori and M. Aoyagi-Usui, 2002. Voluntary adoption of ISO 14001 in Japan: Mechanisms, stages and effects. Busin. Strat. Environ., 11: 43-62. DOI: 10.1002/bse.318

West, P., J. Igoe and D. Brockington, 2006. Parks and peoples: The social impact of protected areas. Annual Rev. Anthropol., 35: 251-277. DOI: 10.1146/annurev.anthro.35.081705.123308

Whitecotton, R.C.A., M.B. David, R.G. Darmody and D.L. Price, 2000. Impact of foot traffic from military training on soil and vegetation properties. Environ. Manage., 26: 697-706. DOI: $10.1007 / \mathrm{s} 002670002224$ 
Williams, L.R., T.H. Bonner, J.D. Hudson, M.G. Williams and T.R. Leavy et al., 2005. Interactive effects of environmental variability and military training on stream biota of three headwater drainages in Western Louisiana. Trans. Am. Fisheries Soc., 134: 192-206. DOI: 10.1577/FT03106.1

Wilson, S.D., 1988. The effects of military tank traffic on prairie: A management model. Environ. Manage., 12: 397-403. DOI: 10.1007/BF01867529

Woodward, J.T., 1994. Commonwealth Commission of Inquiry, Shoalwater Bay, Capricornia Coast Queensland. A.G.P.S., Canberra.

Wu, W. and X.H. Wang, 2011. Development of an environmental performance indicator framework to evaluate an environmental management system for Shoalwater Bay Training Area, Queensland, Australia. Labour Manage. Development, 11: 1-26.

Wu, W., 2012. Evaluating the Australian Defence Force Environmental Management System: A Case Study of Shoalwater Bay Training Area, Queensland. Ph.D thesis, The University of New South Wales, pp: 214.
Wu, W., X.H. Wang, D. Paull and J. Kesby, 2010. Defence force activities in marine protected areas: Environmental management of Shoalwater Bay Training Area, Queensland, Australia. Chinese J. Oceanol. Limnol., 28: 667-676. DOI:10.1007/s00343-010-9113-3

Zackrisson, M. and M. Enroth, 2000. Environmental management systems-paper tiger or powerful tool. Proceedings of the Eco-Management and Auditing Conference, (EMAC' 00), University of Manchester, UK., pp: 81-92.

Zutshi, A. and A.S. Sohal, 2001. Environmental management systems implementation: Some experiences of Australian auditors. Monash University, Victoria.

Zutshi, A., A.S. Sohal and C. Adams, 2008. Environmental management system adoption by government department/agencies. Int. J. Public Sector Manage., 21: 525-539. DOI: $10.1108 / 09513550810885813$ 